\title{
Argemone mexicana L.: A weed with versatile medicinal and pharmacological applications
}

\author{
Afroz Alam* and Adnan A. Khan* \\ Department of Bioscience and Biotechnology, Banasthali Vidyapith, Banasthali-304022, Rajasthan, India \\ *Division of Nephrology and Hypertension, Department of Medicine, University of California, San Diego, Suite Plaza 1, 4510 Execute Drive, \\ San Diego-92121, USA
}

\section{Article Info}

\section{Article history}

Received 3 March 2020

Revised 19 April 2020

Accepted 22 April 2020

Published online 30 June 2020

Keywords

Argemone mexicana L.

Medicinal uses

Papaveraceae

Phytochemical

Weed

\begin{abstract}
Among the huge floral diversity many plants are considered wild or weed with no economical value, hence, somewhat neglected. Argemone mexicana L., is one such wildly growing weed in almost all the regions of Rajasthan. This herb can thrive well without any special attention because of its combatant genomic ability to produce defensive phytochemicals under stress conditions. These phytochemicals also have ample medicinal importance and other uses. In this review several noteworthy medicinal utilization and some hazardous effects of this plant have been highlighted.
\end{abstract}

\section{Introduction}

On this green planet, there are uncountable plants that are considered wild/weed/unwanted due to lack of obvious economical value. However, these plants have adapted well to harsh conditions and thrive very well without any special attention. But, every organism created by Mother Nature has its value, nothing is useless. Hence, these herbaceous weeds also have something valuable in their genomic constitution, but they need sharp eyes and great passion to be explored scientifically in sustainable manner. In past many of the plants that were considered useless are now proven very important in terms of their phytochemicals. The wild herbs/shrubs and trees actually are the great reservoirs of novel phytochemicals and hence one aspect of biodiversity research is to conserve these precious gene pools before they become extinct.

Argemone mexicana (AM) is native to Mexico and presntly prevalent yearly weed of family Papaveracea, mainly connected with farming crops and harsh environments. It is a chief weed for numerous cash of crops in the tropical, sub-tropical and humid temperate parts of the world. The vernacular names of this plant are Mexican prickly poppy, flowering thistle, Cardo/Cardosanto, etc. In India, this plant is variously known as Agara/Bharband/Bharbhar/Brahamadandi/ Kantakusama/Peela Kanteela, etc. This exacting plant species is

Corresponding author: Dr. Afroz Alam

Associate Professor, Department of Bioscience and Biotechnology, Banasthali Vidyapith, Banasthali-304022, Rajasthan, India

E-mail: afrozalamsafvi@gmail.com

Tel.: +91-9785453594

Copyright () 2020 Ukaaz Publications. All rights reserved.

Email: ukaaz@yahoo.com; Website: www.ukaazpublications.com considered as a risk to healthiness if taken with contaminated food because it causes intense itchiness, is an annoyance to the farmers. A. mexicana has been confirmed as poisonous as its seeds represent a risk to human or animal wellbeing when consumed accidentally (NDA, 2001).

1. Taxonomic rank of the plant: Phylum: Spermatophyta; Class: Dicotyledonae; Order: Papaverales; Family: Papaveraceae; Genus: Argemone; Species: Argemone mexicana L.

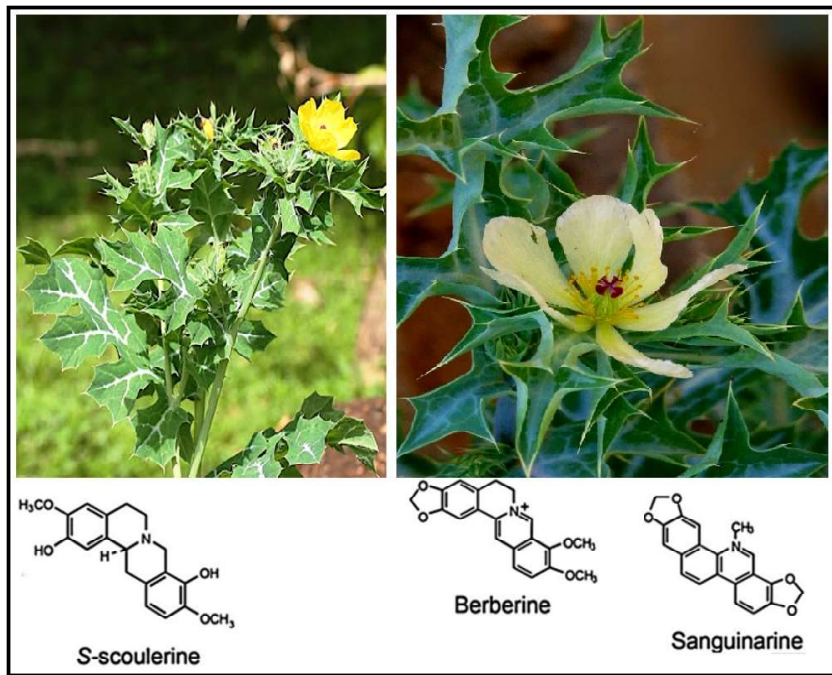

Plate 1: Figure a: A. mexicana L., growing in wild; Figure b: A portion enlarged showing solitary flower; Figure c: Important phytochemicals isolated from this weed (Source: google images). 


\subsection{Historical background}

A. mexicana has been inadvertently introduced through seeds as a showy plant. Apart from this some of the tribes used to cultivate this plant basically for ethnic uses (Healy, 2016; APPEAR, 2016; PROSEA, 2016), the plant is still comparatively infrequent and assumed that it may become a difficult challenge for arable land in the future. Being an annual herb with a soaring possibility of the auxiliary spread since the plant is still considered as an attractive showy plant across the world. The occurrence of species is very frequent at the sites of construction and it is also preferred for landscaping of any new landscape (Foxcroft et al., 2006). The seeds of this plant are used to disperse easily through contaminated seed products, soils and, crop (Healy, 1961; PROTA, 2016).

\subsection{Taxonomic description}

Argemone name was taken from the Greek word 'argena', sense 'cataract of the eye', and this name was used by the orthodox researchers, viz., Dioscorides (AD 40-90) and Pliny (AD 23-79) basically for a number of prickly poppies, the fluid of which was apparently considered as a cure for cataract. The term 'mexicana' coalesces Mexico with the Latin suffix ' $a n a$ ', taken from the source nation (Parsons and Cuthbertson, 1992). A. mexicana is a twelvemonthly herbaceous plant, up to $120-150 \mathrm{~cm}$ elevation with a faintly branched tap root system. The stem is upright, pronged, generally spiny, pale to bluish-green in color (Plate 1: Figure a) and exudes an offensive smelled the yellow juice when cut. Foliages are alternate, petioles absent, roughly covering the stem, equal to $15 \mathrm{~cm}$ long, acutely lobed with sporadically toothed, prickly margins; veins are conspicuous, grayish-white. Flowers borne singly, 2.4$4.6 \mathrm{~cm}$ in diameter, having 1-2 green bracts; calyx 3, spiny; corolla 4-6, yellow to orange, surface glabrous; stamens several (Plate 1: Figure b). Fruit is a capsule, prickly, $2.5-4.5 \mathrm{~cm}$ long and $2 \mathrm{~cm}$ broad, amid 4-6 valves with aperture at the tip to release abundant brownish-black, nearly spherical seeds having the diameter of about $1 \mathrm{~mm}$, a fine network of veins present, oily in nature (Lucas, 1962).

\subsection{Distribution in India}

In India, this species is prevalent in states like, Andhra Pradesh, Assam, Bihar, Delhi, Gujarat, Karnataka, Madhya Pradesh, Maharashtra, Tamil Nadu, Telangana, Rajasthan, Uttar Pradesh, and West Bengal (Sharanappa and Vidyasagar, 2014).

\subsection{Distribution in rest of the World}

This plant species is usually spread in all parts of the world. AFRICA: Nigeria, Namibia, Niger, Senegal, Seychelles, Sierra Leone, Somalia, South Africa, Sudan, Tanzania, Togo, Uganda, Zambia, Zimbabwe; ASIA: Bahrain, Bangladesh, Bhutan, Cambodia, China, Hong King, Indonesia, Java, Japan, Pakistan; MIDDLE EAST: Israel, Saudi Arabia, Turkey, Iran, Iraq, Syria; EUROPE: Italy, Spain, Switzerland, United Kingdom; NORTH AMERICA: United States of America, Anguilla, Antigua, Barbados, Belize, Canada, Hawaii: SOUTH AMERICA: Argentina, Bolivia, Brazil, Chile, Columbia, Ecuador, Guyana, Peru, Uruguay; OCEANIA: Australia, Fiji, New Zealand (Bodeker and Graz, 2013).

\subsection{Habitat}

A. mexicana is tailored to an extensive variety of habitats. The plant prefers the areas having a distinctive dry period (PROTA, 2016). It usually crops up as a common weed of agricultural land, pastures and in dumping yards, railways, roadsides, etc.

\section{Affected plants by this weed}

A. mexicana is a weed for the majority of cropping systems, including millets, cereals, vegetables, legumes, fibre yielding crops (sisal, cotton) and perpetual crops like coffee and sugar cane. It appears that any crop has the impending to be contaminated with $A$. mexicana if grown within the habitat array of this plant.

\subsection{Economic Impact}

Apart from a principal weed of millets, cereals, cotton, vegetables, coffee, timber and fibre yielding plants, this plant is also considered as a potent contaminant in poultry and for grazing animals. The species produces aflatoxins of poisonous nature that are lethal to herbivorous animals, which even found in affected cattles' milk, eggs and their mutton based products (Alemayehu and Desalegn, 2016).

\subsection{Environmental impact}

Islam et al. (2003) has discovered that this weed reduces biodiversity (Kumar and Rohatgi 1999). The plant is known to produce certain allelochemicals that can affect the seed germination, subsequent growth and content of photosynthetic pigments in nearby plants in native ecosystems (Namkeleja et al. (2014).

\subsection{Social impact}

A. mexicana has main hammering on human wellbeing in India and adjacent nations, where the safe to consume vegetable oil either unintentionally tainted with this weed or deliberately mixed by dodgy traders. Dropsy epidemic (Delhi; 1998) is a well known example of this unlawful act (Jha et al., 2001; Sharma et al., 2002). Sharma et al. (1999) reviewed the scientific effects of adulterated oil and recommended precautionary measures. Furthermore, in the northern parts and central parts of India, this weed has been recognized as a potent allergen (Singh and Kumar, 2004).

\section{Uses}

\subsection{Economic worth}

A. mexicana has revealed significant antimicobial action against the bacteria strains, viz., Staphylococcus agalectiaei, S. aureus and Escherichia coli, with impending in the pharmaceutical production (Alemayehu and Desalegn, 2016). This weed has been cultivated for its seed oil, which is specifically used at industrial scale for soap manufacture and also for fuel production (Hanelt and IPK, 2016).

\subsection{Social benefit}

A. mexicana is used for spiritual reasons by many tribes (Hanelt and IPK, 2016). The extracts of the leaves, floral buds and seeds of this weed have been evaluated in laboratory conditions for their insectidal potential (Chitra et al., 1997), common crop pathogens (Singh et al., 1993) and also against nematodes (Das and Sukul, 1988; Saxena and Tabassum, 2000; Shaukat et al., 2002). Aqueous extracts were successfully assessed against, Lipeurus lawrensis tropicalis (Kumar et al., 2002). Few researches recommended that the root extracts can be utilized to avert oviposition and work as ovicidal in opposition to Aedes aegypti (Warikoo and Kumar, 2014). Von Weizsäckerl (1995) stated that this weed is used in India to set up an antifeedant spray similar as the foliage of Azadirachta indica (Neem). Plant extracts of $A$. mexicana eagerly kill the Biomphalaria glabrata (snail) and thus regarded as molluscide for the fairly economical management of schistosomiasis in humans (Melendez and Capriles, 2002). 


\subsection{Medicinal value}

Medicinal possessions have been recognized to the seed sap and its oil (Holm et al., 1977). Ethnobotanically the entire plant is used as a blend to cure asthma. The root is mixed with alcohol (rum) to cure stomach pain. The sap of the stem (cut ends) is useful for the cure for toothache. Kids having obscure urination are given mixtures of petals (DeFilipps et al., 2004). In Madhya Pradesh (India) it is designated as a homeopathic preparation (Oudhia et al., 1998). In African nations, leaves of the plant are used as a cosmetic (Rukangira, 2001). The seeds are ground and mixed with beer/tea to augment their strength (Verdcourt and Trump, 1969). In India, the minute quantity of seeds of this plant is mixed with mustard oil to increase its pungency, however, above that minute quantity the mixing of its seeds to mustard is considered as an adulteration.

\subsection{Environmental services}

Although this herb species has been stated as toxic to animals, however, this plant is palatable by lemurs, which were seen consuming the stems of this weed when other resources were insufficient after a destructive cyclone in Madagascar. Those lemurs were then observed and no harmful concerns related to normal healthiness were reported by the researchers (LaFleur and Gould, 2009). Hence it can be concluded that the shoots are risk free and only seeds have toxic substances.

\subsection{Ethnobotanical uses}

Among many tribes this plant has certain ritual uses which are evident by their folklores (Hanelt and IPK, 2016). The different parts of this weed posses strong emetic, sedative actions and conventionally been used to take care of syphilis and various skin-diseases (Krishnamurthy, 1969; Savithramma et al., 2007). In cough and asthma seeds are given as a remedy. Seeds are also found laxative in nature with emetic, expectorant and demulcent properties. The root is an anti-helmintic (Nadkarni, 1982). Chemical characterization of this plant has discovered the existence of certain alkaloids, amino acids, phenolics and fatty acids (Hussain et al., 1983; Harborne and Williams, 1983).

The plant contains several alkaloids, viz., protopine, berberine, sarguinarine, optisine, chelerytherine etc. While, the seed oil has fatty acids, viz., palmitic, myristic, oleic, linoleic acids, etc. The sap of the plant is yellow and contains minute quantities of berberine, also potassium nitrate was identified among the salts naturally existing in the plant.

\subsection{Phytochemical evaluation}

A huge number of phyto-constituents have been isolated and characterized from different plant parts, viz., alkaloids, phenolics, amino acids and fatty acids. Four quaternary isoquinoline alkaloids, jatrorrhizine, columbamine, dehydrocory-dalmine, and oxyber- berine, have been isolated from the whole plant of $A$. mexicana and their structures recognized by spectral confirmation (Papova et al., 1980; Das and Khanna 1997; Singh et al., 2010). Compounds of aliphatic nature viz., mexicanic acid and mexicanol have been isolated from leaves of $A$. mexicana. Likewise, from seeds, isoquinoline alkaloids such as dihydropalmitine hydroxide; protopine and berberine have been isolated (Plate 1: Figure c). The seed oil contains $40 \%$ free glycerides of fatty acids (Anonymous, 2004). This plant conventionally used as an effective diuretic remedy. Furthermore, the plant exhibits anti-inflammatory, antihelmintic, injury healing, and anti-microbial properties (Bhattacharjee et al., 2006).
The plant is known as an astringent, pungent, purgative, seditious, expectorant, emetic, antipyretic, ophthalmic, stomachic. The plant is remarkable in curing disease like leprosy, other skin infections, swelling, etc. (Prasanna et al., 2007).

Roots are found valuable in the case of guinea-worm invasion, skin diseases, leprosy, inflammations, poisoning, digestive disorders (flatulence and constipation), colic, malaria, etc., (Sharanappa and Vidyasagar, 2014). Seeds are purgative and tranquillizer; they have a remarkable resemblance with mustard seeds and hence occasionally used to mixed with mustard seeds for unlawful monetary gain (Pahwa and Chatterjee, 1989). The seeds produce a non edible lethal oil and causes fatal dropsy disease when used with mustard oil for cooking and show lots of noxious effect. Seeds are also useful in irritable cough, asthma, pertussis, leprosy, skin diseases, injuries, dental caries, rheumatalgia, constipation, flatulence and colic condition (Bhattacharjee et al., 2006).

The leaves are useful in curing cough and cold, injuries, newly developed ulcers and in various skin diseases caused by microorganisms. Leaf juice is used in ophthalmology to treat opthalmia and murkiness of the cornea (Orient Longman, 1998).

The latex is useful in dropsy, leprosy, skin diseases, blisters, jaundice, conjunctivitis, burning sensation, inflammation and malaria (Kirtikar and Basu, 1991).

Though the oil is known to cause dropsy yet found useful in the treatment of leprosy, skin diseases, indolent ulcers, injuries, flatulence, constipation, colic and rheumatalgia. In homeopathy, a drug extracted from this plant is used to cure the trouble caused by the tape worm (Bhardwaj et al., 1982).

A problem known as 'Hepatotoxicities' is extensively came across worldwide due to the toxicity caused by this plant when used in higher doses, and considered as one of the ten foremost causes of death globally, thus, there is a great need to perform toxicity related research to resolve the safe dose for variously stated pharmacological action. There is a need to work and identify the various isolated phyto-constituents, along with their pharmacological activity with finely calculated doses to avoid toxicity. Consequently, several researches are going on with this herb that have mainly concentrated on its hepatoprotective action, anti-microbial potential (Bhattacharjee et al., 2006), anti HIV activity (Chang et al., 2003a) and cytotoxic potential (Chang et al., 2003b).

\section{Major pharmacological analysis}

4.1 Hepatoprotective activity

The bark of root was examined on CCl4 (Carbon tetra Chloride) tempted liver damaged (rat model). Severe toxicity study, efficiency status, blood test and biochemical assays of the tissue (ALT, AST, total protein, glucose, bilirubin, LM and EM), etc., have been evaluated for Hepato-protective act. On the basis of results it was exhibited that this herb certainly has an elevated prospective in a curative role like healing of liver parenchyma and renewal of damaged liver cells hence considered as an effective liver tonic (Pingale et al., 2008).

\subsection{Antimalarial activity}

A decoction of $A$. mexicana was evaluated in increasing doses to find out the suitability of the decoction as healer for the treatment of malaria. It was found that the malaria patients showed enhanced ability to recover when treated with controlled doses of decoction. However, complete clearance of Plasmodium falciparum was not achieved (Willcox et al., 2007). 


\subsection{Antibacterial activity}

The basic extracts of $A$. mexicana foliage and seeds of were assessed by agar well diffusion technique to find out their potential against Staphylococcus aureus and Bacillus subtilis (Gram+ bacteria), Escherichia coli and Pseudomonas aeruginosa (Gram- bacteria) which are known as pathogenic and multi-drug resistant. Although, all the extracts were found efficient, hitherto the methanol extract exhibited utmost reticence against the selected bacterial strains, followed by warm aqueous extracts and cold aqueous extract, respectively (Sakthivadivel et al., 2003). Likewise, the alcoholic and petroleum ether extracts of above ground parts of this herb were assessed for antimicrobial activity against, Bacillus subtilis (Gram+) and Escherichia coli (Gram-). Which showed high antibacterial activity on the bacterial strains, however the alcoholic extract showed superior action compared to the petroleum ether extract (Bhattacharjee et al., 2006).

\subsection{Antiplasmodial activity}

A. mexicana also showed antiplasmodial activity at varying doses of extract (per kg/body wt.) About twenty species of genus Argemone have been evaluated and it was found that with the IC50 values of 9$43 \mathrm{mg}$ dry extract $\mathrm{ml}^{-1}$ these species possess antiplasmodial activity, e.g., plant extracts [in vitro inhibition (\%)] against chloroquine liable strain of P. falciparum (Simonsen et al., 2001).

\subsection{Cytotoxic activity}

By fractionation of the plant's extract (in chloroform), an alkaloid was isolated and subsequently tested for its cytotoxicity to human being nasopharyngeal carcinoma and gastric cancer cell lines. Later, the alkaloid chelerythrine showed significant activity against cancerous cell line, whilst angoline was reported as potent inhibitor of cancerous cell lines (Chang et al., 2003).

\subsection{Larvicidal action}

A. mexicana extract in petroleum ether at higher concentrations, after acetone fraction showed larvicidal properties and also growth restraining action in opposition to the subsequent (second) instar larvae of Aedes aegypti (Sangameswaran et al., 2004).

\subsection{Vasorelaxant action}

The vascular effects of a methanolic extract of the above ground plant parts of $A$. mexicana was explored in aortic rings of rat. Remarakbly, the extract created relaxation from contraction tempted by norepinephrine in a dose-dependent mode. At elevated doses (300 and $1000 \mu \mathrm{g} \mathrm{ml}^{-1}$ ), the extract caused noteworthy added stress. The results showed that the extract encourages a straight dual explicit consequence upon the smooth muscle, partly mediated by adrenergic receptors (Páez-Sánchez et al., 2006).

\subsection{Injury curative action}

The curative effects for an injury of the foliage extract (in $50 \%$ ethanol) and latex of $A$. mexicana plants were examined in an albino rat model, using excision and incision injuries both. Topical use of the plant extract and its latex, correspondingly, conferred approximately 67 and $57 \%$ curing after 12 days in the cutting out mode and augmented tensile potency to about 190 and $155 \mathrm{gm}$ in the slit out mode. Though, the plant extract and latex both were not found as successful as the customary nitrofurazone salt (Ghosh et al., 2005).

\subsection{Anti-HIV action}

In the methanolic extract of $A$. mexicana few alkaloids have been isolated and were evaluated for their anti-HIV action, viz., benzo[c]phenanthridine (+/-)-6-acetonyldihydro chelerythrine showed noteworthy anti-HIV action in H9 lymphocytes cells with EC50 and TI values of $1.77 \mu \mathrm{ml}^{-1}$ and 14.6, respectively (Chang et al., 2003).

\subsection{Antiasthmatic action}

A. mexicana seed powder (100-200 mg) taken twice daily for 2 weeks showed noteworthy outcome on the incidence of asthama as antiasthamatic activity (Bhalke and Gosavi, 2009).

\subsection{Antistress and antiallergic action}

Stem of $A$. mexicana in asthma induced by leucocytosis and milkinduced eosinophilia showed antiallergic and anti-stress impending. This showed that polar constituents of plant stem are conscientious for antistress and antiallergic activity (Piacente et al., 1997).

\subsection{Molluscicidal action}

Molluscicidal possessions of seeds of this weed against snail Lymnaea acuminata were done. It was observed that the molluscicidal action of plant's seed powder was both time and dose dependent. In seed powder, protopine and sanguinarine were recognized as the active component caused snail fatality by co-migration of a vigorous agent (Singh and Singhm 1999; Meléndez and Capriles, 2002).

\subsection{Opoid withdrawal}

In the methanolic plant extract, the pure compounds isolated as protopine and allocryptopine from A. mexicana that were found significantly active in a dose-dependent manner to reduce the morphine toxicity, hence suggesting that these alkaloids may be impending agents in the handling of morphine mistreatment (Capasso et al., 1997).

\subsection{Lethality and safety estimate}

From the seeds of $A$. mexicana, an alkaloid sanguinarine was isolated and evaluated for its hepatotoxic potential in rat model. The study revealed that a single i.p. dose $\left(10 \mathrm{mg} \mathrm{kg}^{-1}\right)$ of this alkaloid, not only augmented the action of SGPT and SGOT significantly, but also created a noteworthy trouncing of P-450 (microsomal cytochrome) and the activity of benzphetamine N-methylase. In addition, the experimented rat exhibited substantial lowering in the body and liver weight, along with somewhat inflamed liver with fibrinous stuff. Further microscopic inspection of the hepatic tissue confirmed progressive cellular deterioration and cell death (Dalvil and Sanguinarine, 1985; Das et al., 2009).

\section{Conclusion}

Plants are our natural healers, and not a single plant on this earth is futile (Alam, 2019). Nature has something in everything either explored or unexplored till date (Nooreen et al., 2018). On the basis of a number of studies, regarding this weed it is apparent that this habitually ignored, but remarkably shown plant of the arid regions remarkably has a range of benefits related to health issues beside its illegal utilization as a contaminant in mustard oil. The curative value exists in its hepato-protective nature, antimalarial, 
antibacterial, antiplasmodial, antiasthamatic, antiallergic, anti-HIV properties, etc. Beside, these it has cytotaxic ability against cancerous cell lines. The plant is also used to treat, leprosy, skin diseases and to cure injuries. The plant parts also showed vaso-relaxant, larvicidal and molluscicidal action. Its phytochemical composition includes several useful alakaloids and antioxidants of pharmaceutical importance (Magaji et al., 2019). In ethnomedicinal culture, this herb has been extensively utilized to treat local infections and to mitigate the impact of high doses of morphine. Though, this weed is of common occurrence in different regions of India and abroad, its status as phytomedicinal herb yet to achieve, it is one of the least studied plants in spite of having huge medicinal value. This review recognizes the significance of $A$. mexicana somewhat equal to another member of family Papaveraceae, Papaver somniferum (opium poppy) to be a focus for the researcher in the area of phytomedicine/herbal formulations to add and explore this incredible plant in the floral wealth of this planet.

\section{Acknowledgements}

The author wish to acknowledge Bioinformatics Center, Banasthali Vidyapith supported by DBT for providing computational support, and also acknowledge DST for providing networking support through the FIST program at the Department of Bioscience and Biotechnology.

\section{Conflict of interest}

The authors declare that there are no conflicts of interest in the course of compiling the review article. Both the authors had final decision regarding the manuscript and decision to submit this work for publication.

\section{References}

Alam, A. (2019). Herbs that heal Spices: The hoard of natural remedies. Ann. Phytomed., 8(2):7-18.

Alemayehu, K. and Desalegn, T. (2016). Antibiotic effects of Argemone mexicana (Papaveraceae) against field crops and pathogens causing mastitis in Dairy Cattle in three districts of Amhara Region, Ethiopia. Journal of Advances in Biology and Biotechnology, 5(1):1-9.

Anonymous (2004). In: The Wealth of India A Dictionary of Indian Raw Materials and Industrial Products. Council of Scientific and Industrial Research, New Delhi, 1:86-87.

APPEAR (2016). Monograph-Argemone mexicana. MEAMP - Appear Project - 75, September 2012 - August 2014. Austrian Partnership Programme in Higher Education and Research for Development.

Bhalke, R.D. and Gosavi, S.A. (2009). Antistress and antiallergic effect of Argemone Mexicana Stems in Asthma. Archives of Pharmaceutical Science and Research, 1(1):127-129.

Bhardwaj, D. K.; Bisht, M. S.; Jain, R. K. and Munjal, A. (1982). Phenolics from the seeds of Argemone Mexicana. Phytochemistry, 21(8):2154-2156.

Bhattacharjee, I.; Chatterjee, S.K.; Chatterjee, S. and Chandra, G. (2006). Antibacterial potentiality of Argemone mexicana solvent extracts against some pathogenic bacteria. Memórias do Instituto Oswaldo Cruz, 101(6):645-648.

Bodeker,G. and Graz, B. (2013). Traditional Medicine. In: Hunter's Tropical Medicine and Emerging Infectious Disease (Ninth Edition), pp:197-2022.
Capasso, A.; Piacente, S.; Pizza, C.; De Tommasi, N.; Jativa, C. and Sorrentino, L. (1997). Isoquinoline alkaloids from Argemone mexicana reduce morphine withdrawal in guinea pig isolatedileum. Planta Medica, 63(4):326-328.

Chang, Y.C.; Chang, F.R.; Khalil, A.T.; Hsieh, P.W. and Wu, Y.C. (2003b). Cytotoxic benzophenanthridine and benzylisoquinoline alkaloids from Argemone mexicana. Zeitschrift für Naturforschung, 58(7-8): 521-526.

Chang, Y.C.; Hsieh, P.W.; Chang, F.R.; Liaw, C.C.; Lee, K.H. and Wu, Y.C. (2003a). Two new properties argemexicaines $\mathrm{A}$ and $\mathrm{B}$ and the anti-HIV alkloid 6-acetonyldihydrochelerythrine from Argemone mexicana. Planta Medica, 69:148-152.

Chitra, K.C.; Rao, S.J. and Rao, P.K. (1997). Efficacy of plant extracts for controlling cotton aphid (Aphis gossypii). Indian Journal of Agricultural Sciences, 67(3):134-135.

Dalvil, R.R. (1985). Sanguinarine:Its potential as a liver toxic alkaloid present in the seeds of Argemone mexicana. Experientia, 41(1):77-78.

Das, P.K.; Panda, P.; Pani, S.R. and Sethi, R. (2009). Hepatoprotective activity of plant Argemone mexicana (Linn). Against carbon tetrachloride $\left(\mathrm{CCl}_{4}\right)$ induced hepatoxicity in rats. International Journal of Pharmaceutical Research and Development, 8:1-20.

Das, S. and Sukul, N.C. (1988). Nematicidal effect of the oil from the seeds of Argemone mexicana. Environment and Ecology, 6(1):194-197.

DeFilipps, R.A.; Maina, S.L. and Crepin, J. (2004). Medicinal Plants of the Guianas (Guyana, Surinam, French Guiana). http://www.mnh.si.edu/ biodiversity/bdg/medicinal

Foxcroft, L.C.; Lotter, W.D.; Runyoro, V.A. and Mattay, P.M.C. (2006). A review of the importance of invasive alien plants in the Ngorongoro Conservation Area and Serengeti National Park. African Journal of Ecology, 44(3):404-406.

Ghosh, T.; Dash, G.K.; Bose, A. and Panda, B.R. (2005). Wound healing properties of Argemone mexicana. Indian Journal of Natural Products, 20:3-6.

Hanelt, P. and IPK. (2016). Mansfeld's World Database of Agricultural and Horticultural Crops. Gatersleben, Germany: Leibniz Institute of Plant Genetics and Crop Plant Research (IPK). http://mansfeld.ipkgatersleben.de/apex/f?p=185:3:0::NO

Harborne, J.B. and Williams, C.A. (1983). Flavonoids in the seeds of Argemone mexicana: A reappraisal. Phytochemistry, 22(6):15201521 .

Healy, A.J. (1961). The interaction of native and adventive plant species in New Zealand. Proceedings of the New Zealand Ecological Society, 8:39-43

Holm, L.G.; Plucknett, D.L.; Pancho, J.V. and Herberger, J.P. (1977). The World's Worst Weeds. Distribution and Biology. Honolulu, Hawaii, USA: University Press of Hawaii.

Hussain, S. F.; Nakkady, S.; Khan, L. and Shamma, M. (1983). Oxyhydrastinine, an Isoquinolone Alkaloid Papaveraceae. Phytochemistry, 22(1):319-320.

Islam, M.; Ruhul Amin, A.S.M. and Sarker, S.K. (2003). Bangladesh. In: Pallewatta N, Reaser JK, Gutierrez AT. eds. Invasive alien species in South-Southeast Asia: National reports and directory of resources. Cape Town: Global Invasive Species Programme, pp:7-20.

Jha, N.; Yadav, B.K. and Pokharel, P.K. (2001). Knowledge on epidemic dropsy among the health workers of Sunsari, Nepal. Journal of the Nepal Medical Association, 40(138):53-56. 
Kirtikar, K.R. and Basu, B.D. (1991). Indian Medicinalplants. Vol. I, II ${ }^{\text {nd }}$ Edn., Delhi, Sri Satguru Publications, pp:129-131.

Krishnamurthy, A. (1969). The wealth of India. Vol VIII, publication and information directorate, CSIR, New Delhi, 1969:415-417.

Kumar, S. and Rohatgi, N. (1999). The role of invasive weeds in changing floristic diversity. Annals of Forestry, 7(1):147-150

Kumar, S.; Singh, S.K.; Baslas, R.K.; Ghildiyal, J.C. and Saxena, A.K. (2002). Lousicidal properties of few aqueous plant extracts. Indian Veterinary Journal, 79:1136-1140

Lucas, G.L. (1962). Papaveraceae. In: Hubbard CE, Milne-Redhead E, eds. Flora of tropical East Africa. London, UK: Crown Agents for Oversea Governments and Administrations.

Magaji, M.B.; Haruna, Y. and Muhammad, A. (2019). Phytochemical screening and antioxidant activity of argemone mexicana leaf methanol extract. Annals of Pharmacology and Pharmaceutics, 4(1): 1167

Meléndez, P.A. and Capriles, V.A. (2002). Molluscicidal activity of plants from Puerto Rico. Annals of Tropical Medicine and Parasitology, 96(2):209-218

Nadkarni, K.M. (1982). In Indian Materia Medica. Published by Bombay Popular Prakashan, 1:133.

Namkeleja, H.S.; Tarimo, M.T.C. and Ndakidemi, P.A. (2014). Allelopathic effects of Argemone mexicana to growth of native plant species. American Journal of Plant Sciences, 5(9):1336-1344.

NDA (2001). Agricultural Product Standards Act (Act No. 119 of 1990) - Regulations relating to the grading, packing and marking of sunflower seed intended for sale in the Republic of South Africa. Government Gazette, No. 22610:4-11.

Nooreen, Z.; Rai, V.K. and Yadav, N.P. (2018). Phytopharmaceuticals: A new class of drug in India. Ann. Phytomed., 7(1):27-37.

Orient Longman (1998). Indian medicinal plants (a compendium of 500 species). 1:186-187.

Oudhia, P.; Joshi, B.S. and Kosta, V.K. (1998). The possibilities of preparing homeopathic drugs from the obnoxious weed of Chhattisgarh. Bhartiya Krishi Anusandhan Patrika, 13(1/2):53-57.

Páez-Sánchez, E.; Fernández-Saavedra, G. and Magos, G.A. (2006). Vasoconstrictor and Vasorelaxant Effects of a Methanolic Extract from Argemone Mexicana Linn (Papaveraceae) in Rat Aortic Rings, Proceedings of the Western Pharmacology Society, 49:63-65.

Pahwa, R. and Chatterjee, V.C. (1989). The toxicity of Mexican poppy Argemone mexicana L. seeds to rats. Journal of Veterinary and Human Toxicology, 31(6):555-558.

Parsons, W.T. and Cuthbertson, E.G. (1992). Noxious Weeds of Australia. Melbourne, Australia: Inkata Press, pp:692.

Piacente, S.; Capasso, A.; Tommasi, N.D.; Jativa, C.; Pizza, C. and Sorrentino, L. (1997). Different effects of some isoquinoline alkaloids from Argemone mexicanaon electrically induced contractions of isolated guinea-pig ileum. Phytotherapy Research, 11(2):155-157.

Pingale, S.S.; Pokharkar, R.D. and Pingale, M.S. (2008). Effect of Argemone mexicana L. root bark on evaluation of Hepatoprotective action in rats. Pharmacology online, 1:13-19.
Prasanna, V.; Joshi, H.H. and Patil B.S. (2007). Potential wound healers from plant origin. Pharmacognosy Reviews, 1(2):14-28.

PROSEA (2016). Plant Resources of South-East Asia. http://uses.plantnetproject.org

PROTA (2016). PROTA4U web database. Grubben GJH, Denton OA, eds. Wageningen, Netherlands: Plant Resources of Tropical Africa. http://www.prota4u.org/search.asp

Rukangira, E. (2001). The African herbal industry: constraints and challenges. Erboristeria Domani. www.conserveafrica.org.uk/ herbal_industry.pdf

Sakthivadivel, M. and Thilagavathy, D. (2003). Larvicidal and chemosterilant activity of the acetone fraction of petroleum ether extract from Argemone mexicana L seed. Bioresource Technology, 89(2):213-216.

Sangameswaran, B.; Balakrishnan, B.R.; Arul, B. and Jayakar, B. (2004). Antimicrobial activity of aerial parts of argemone mexicana linn. Journal of Ecotoxicology and Environmental Monitoring, 14(2): 143-146.

Savithramma, I.; Sulochana, Ch. and Rao, N.K. (2007). Ethnobotanical survey of plants used to treat asthma in Andhra Pradesh, India Journal of Ethnopharmacology, 113(1):54-61.

Saxena, R. and Tabassum, B. (2000). Aqueous weeds extract: An ecohealthy approach for nematode management. Current Nematology, 11:29-33

Sharanappa, R. and Vidyasagar G.M. (2014). Plant profile, phytochemistry and pharmacology of Argemone mexicana Linn. A Review. International Journal of Pharmacy and Pharmaceutical Sciences, 6(7):45-53.

Sharma, B.D.; Bhatia, V.; Rathee, M.; Kumar, R. and Mukharjee, A. (2002). Epidemic dropsy: Observations on pathophysiology and clinical features during the Delhi epidemic of 1998. Tropical Doctor, 32(2):70-75.

Sharma, B.D.; Malhotra, S.; Bhatia, V. and Rathee, M. (1999). Epidemic dropsy in India. Postgraduate Medical Journal, 75:657-661.

Shaukat, S.S.; Siddiqui, I.A.; Khan, G.H. and Zaki, M.J. (2002). Nematicidal and allelopathic potential of Argemone mexicana, a tropical weed. Plant and Soil, 245:239-247.

Simonsen, H.T.: Nordskjold, J.B.: Smitt, U.M.: Nyman, U.; Palpu, P.; Joshi, P. and Varughese, G. (2001). In vitro screening of Indian medicinal plants for antiplasmodial activity. Journal of Ethnopharmacology, 27: 195-204.

Singh, H.N.P.; Prasad, M.M. and Sinha, K.K. (1993). Efficacy of leaf extracts of some medicinal plants against disease development in banana. Letters in Applied Microbiology, 17(6):269-271.

Singh, S. and Singh, D.K. (1999). Molluscicidal property of seeds of Argemone mexicana Chemosphere, 38(14):3319-3328.

Vercourt, B. and, Trump, E.C. (1969). Common Poisonous Plants of East Africa. London, UK: Collins.

von Weizsäckerl, P. (1995). The yield of weeds. ILEIA Newsletter, 11(3):6-7.

Warikoo, R. and Kumar, S. (2014). Oviposition altering and ovicidal efficacy of root extracts of Argemone mexicana against dengue vector, Aedes aegypti (Diptera: Culicidae). Journal of Entomology and Zoology Studies, 2(4):11-17.

Willcox, M.L.; Graz, B.; Falquet, J.; Sidibé, O.; Forster, M. and Diallo, D. (2007). Argemone mexicana decoction for the treatment of uncomplicated falciparum malaria. Transactions of the Royal Society of Tropical Medicine and Hygiene, 101(2): 1190-1198.

Citation: Afroz Alam and Adnan A. Khan (2020). Argemone mexicana L: A weed with versatile medicinal and pharmacological applications. Ann. Phytomed., 9(1):218-223. http://dx.doi.org/10.21276/ap.2020.9.1.29 